\title{
CONDUCTIVITY TO RUST IN COFFEE UNDER DIFFERENT WOODEN AND FRUIT TREE INTERCROPPING SYSTEMS
}

\author{
Sara Maria Chalfoun ${ }^{1}$, Carla de Pádua Martins², Christiano Sousa Machado Matos³, \\ Alessandro Botelho Pereira ${ }^{4}$, Vicentina Nazaré Silva ${ }^{5}$
}

(Received: September 12, 2017; accepted: December 04, 2017)

\begin{abstract}
The coffee intercropping with fruit and wooden species of economic value has been presented as a viable alternative for coffee cultivation in order to mitigate adverse environmental conditions for coffee trees, among other factors. Adapting the crop management to the new conditions stablished by the system is fundamental to obtain success on intercropping. One of the most serious diseases for the crop is the rust caused by Hemileia vastatrix., which may have its severity increased in function of the microclimate conditions provided by the trees. In this sense, the disease behavior under different intercropping systems and consequent different need to adapt the control measures when compared to the cultivation in full sun should be investigated. The present study was conducted aimed to verify the impact of tree systems composed by three wooden species, Cedar (Acrocarpos fraxinifolius), African mahogany (Khaya ivorensis ), Teak (Tectona grandis ) and two species of fruit trees, avocado (Persea Americana) and macadamia (Macadamia integrifolia) planted in different spacing over the occurrence and evolution of rust.It was possible to observe that coffee rust began to progress in the coffee plants from the month of February reaching a peak in September in all the treatments. Differences were observed in the progress curves of the disease, especially in the species that presented larger canopy such as avocado. Further studies are suggested with the purpose of establishing the microclimatic changes provided by the cultivation of different wooden and fruit species in intercropping with coffee, according to the dynamics of the climate and their development.
\end{abstract}

Index terms: Climate changes, shade-grown, sustainability.

\section{CONDUTIVIDADE À FERRUGEM EM CAFÉ SOB DIFERENTES SISTEMAS DE CONSÓRCIO}

RESUMO: A arborização com espécies frutíferas e madeireiras de valor econômico tem se apresentado como uma alternativa viável para a cafeicultura visando, entre outros fatores, atenuar condições ambientais adversas aos cafeeiros. Para que o sistema de consórcio seja bem sucedido torna-se necessário adaptar o manejo da cultura para as novas condições estabelecidas para o sistema de cultivo. Com relação às doenças, entre elas a ferrugem (Hemileia vastatrix.), uma das doenças mais graves para a cultura, pode ter a sua severidade aumentada devido às condições de microclima proporcionadas pelo cultivo arborizado. Dessa forma o conhecimento do comportamento da doença sob diferentes sistemas de consorciação e consequente necessidade de adaptação das medidas de controle em relação ao cultivo a pleno sol, devem ser pesquisadas. A presente pesquisa objetivou verificar o impacto de sistemas de arborização com três espécies madeireiras, Cedro (Acrocarpos fraxinifolius), Mogno Africano (Khaya ivorensis), Teca (Tectona grandis) e duas espécies de frutíferas, abacateiro (Persea americana)e macadâmia (Macadamia integrifolia), plantadas em diferentes espaçamentos sobre a ocorrência e evolução da ferrugem. Foi possível observar que a ferrugem começou a progredir nos cafeeiros a partir do mês de fevereiro, atingindo um índice máximo no mês de setembro para todos os tratamentos. Diferenças foram observadas nas curvas de progresso da doença, especialmente nas espécies que apresentavam maior copa como o abacateiro. Estudos adicionais são sugeridos com a finalidade de estabelecer as mudanças microclimáticas proporcionadas pelo cultivo de diferentes espécies arbóreas e frutíferas consorciadas ao café, em função da dinâmica do clima e do desenvolvimento das mesmas.

Termos para indexação: Mudanças climáticas, sustentabilidade, consórcio.

\section{INTRODUCTION}

The coffee introduced in Asia and Latin America was initially cultivated under shade to retain the physiological attributes of shade plants. In the 1950s, the use of shade was abandoned as a regular practice to increase production in Brazil (DAMATTA and RODRÍGUEZ, 2007) and control of diseases and pests, especially the coffee rust Hemileia vastratix (Berk. \& Br.) and the coffee berry borer (DAMATTA, RENA, 2002).
The model of coffee cultivation adopted in Brazil since the beginning of the $19^{\text {th }}$ century is characterized by monoculture in full sun and therefore with low level of biological diversity, disregarding the idea that coffee can be cultivated below the forest canopy, as in the case of coffee trees from Colombia, Venezuela, Costa Rica, Mexico, Nicaragua, and Panama (AGUIARMENEZES et al., 2007). In this sense, Brazilian research has been driven to find more ecological and economically feasible solutions, especially for

1,2,3,4,5 Empresa de Pesquisa Agropecuária de Minas Gerais/EPAMIG - Cx. P. 176 - 37.200000 - Lavras- MG chalfoun@epamig.ufla.br, carla@deg.ufla.br,christianomatos@epamig.ufla.br,alessandrobot@epamig.ufla.br, vicentinans@epamig.ufla.br 
small and medium-sized farmers, with the aim to adapt crops to climatic changes.

The main effects of shading on coffee cultivation are associated with nutrient cycling; the presence of natural pest and disease controllers; better use of labor in the off-season, attenuation of the damaging action of wind, decrease of air temperature fluctuations around $2-3^{\circ} \mathrm{C}$ and wind velocity and increase of air humidity (VALENTINI et al.2010; OVALLE RIVERA et al., 2015). As a reflection of the shading on the coffee trees, one can observe the production of longer internodes, fewer but larger leaves, obtainment of soft drink coffees (slower maturation), increased coffee production capacity and reduction of biennial production, lower incidence of pointer drought and cercosporiosis, reduction of mechanical damages and injuries that facilitate the penetration of pathogens, reduction of defoliation, low attack of miner, lower incidence of scald and frost, additional income for the use of the tree species and reduction of infestation of weeds in the crop. In addition, there is a growing appreciation of shaded coffee plantations due to their contributions to biodiversity conservation and ecosystem service providence (TSCHARNTKE et al. 2011, IDOL, HAGGAR, COX, 2011; DE BEENHOUWER et al. 2013; MANCUSO et al. 2013). However, intercropping involves a number of aspects to be considered, such as the shadow level, diversity and nature of the shadow of species, number of extracts and horizontal distribution, which effects are in need to be clarified for the development of new "Good Systems" to deal with climate changes and the complex effects on the potential attack of pests and diseases (AVELINO et al. 2007; BOTELHO et al.2015).

The shadow effects on coffee pests and diseases are usually not clear, since the shade can be conducive to a particular process in the life cycle of a harmful organism and hamper another process at the same time. Higher incidences of coffee borer (SANCHEZ et al.,2013) and coffee rust (LOPEZBRAVO et al., 2012) have already been reported in shaded coffee plantations. Damage caused by cercosporiosis (Cercospora coffeicola), a disease that can cause total defoliation in coffee plants, is elevated in unshadowed coffee plantations (STAVER, 2001), probably because of the greater susceptibility of plants under water or nutritional stress. (WRIGLEY, 1988).

In the case of coffee rust, a disease that has relevant importance for Brazilian and world coffee production, the balance of these antagonistic effects is variable and sometimes controversial.
A high percentage of shade can reduce rust attack by reducing production. However, the shade also softens the temperature variation, intercepts light and probably increases the humidity in the crop, although these effects favor the increase of rust (LOPEZ-BRAVO et al., 2012).

Chemical control is the mode of control of coffee rust predominant in full sun cropping systems. Cultivars tolerant to the disease, adapted to the different cultivation regions, are being made available to the coffee growers, so far there has been a low level of substitution of the coffee tree for the new cultivars.(CARVALHO et al. 2012).

Avelino et al. (2015) studied the crisis promoted by the worsening of coffee rust in Colombia and Central America (2008-2013), its impact, probable causes and proposed solutions, mentioning that shade management also affects rust. In Central America, coffee rust intensities were high both in coffee plots under shade and total exposure to the sun. However the impacts in terms of defoliation and dead branches, which are the main factors affecting yield, are not clear. They believe the impacts should have been greater at full sun exposure where coffee plants were particularly stressed due to the rainfall in 2012 . The effect of shade on host defoliation due to rust deserves further investigation.

The intercropping of coffee with tree and fruit species is often cited as an option to improve the ability of family coffee growers to adapt to climatic risks (LASCO et al., 2014), as well as to provide alternative sources of income from coffee products, such as fruits, wood, coal, latex, thus freeing the producer from the cyclical variations of coffee quotations (PEZZOPANE et al., 2010; GOVINDAPPA; ELAVARASAN, 2014). Intercropping presents an alternative income for small producers to plant coffee in the absence of bank credits, while for large producers it may represent an additional income. Therefore, when planning the intercropping, its goals must be considered to define the species to be planted.

The present research aimed to define the effect of using the fruit specie avocado (Persea Americana) and macadamia (Macadamia integrifolia) and the wooden trees Cedar (Acrocarpos fraxinifolius), African mahogany (Khaya ivorensis), Teak (Tectona grandis) planted in different spacing, on the occurrence and evolution of coffee rust in order to define the adequate management of both intercropped and coffee crops, so that both can produce satisfactorily. 


\section{MATERIAL AND METHODS}

The assay was conducted in a private property called Fazenda da Lagoa, located in the municipality of Santo Antônio do Amparo, state of Minas Gerais, a coffee producing region in the south of Minas Gerais State, which coordinates are $20^{\circ} 54^{\prime} 58.1^{\prime \prime} \mathrm{S}$ and $44^{\circ} 51^{\prime} 13.7^{\circ} \mathrm{W}$. The region presents altitude of $1089 \mathrm{~m}$, average temperature of $19.8^{\circ} \mathrm{C}$ and precipitation $1670 \mathrm{~mm} /$ year.

Three wooden species and two fruit trees were planted concomitantly with the coffee crop on December 2012 (cultivar Catuaí - IAC 99). The wooden species Cedar (A. fraxinifolius), African mahogany (K.ivorensis), Teak (T. grandis) and the fruit trees avocado (P. americana) and macadamia $(M$. integrifolia) were planted between the plants in the row of the coffee trees using two spacing. For the wooden species, the spacing were established in $9.0 \times 13.6 \mathrm{~m}$ and $18 \times 13.6$ and for the fruit species the spacing of $7.0 \times 13.6 \mathrm{~m}$ and $14.0 \times 13.6 \mathrm{~m}$ were established for avocado and $5.0 \times 13.6$ and $8.0 \times 13,6$ for macadamia. The control is in full sun.

In the spacing between the rows, three lines of coffee trees were intercalated with the shade species, in total and $13.6 \mathrm{~m}$ between the intercropped lines. The incidence of rust was determined by collecting 100 leaves per plot at each 30 days and counting the number of leaves with symptoms of the disease. Subsequently, the rust, progress curves were defined for the studied period. According to Shaner and Finney (1977), the area below the disease progress curve can be calculated as follows:in which:

$$
A A C P D=\left\{\sum_{j=1}^{n-1}[(y+y) / 2] *\left(t_{i}+1-t_{i}\right)\right\}
$$

Yi: severity of disease (note per plot in $\%$ ) at the ith observation;

$\mathrm{Yi}+1$ : disease severity at the time of the $\mathrm{i}$ +1 evaluation;

$\mathrm{Xi}$ : time (days) in the ith observation;

$\mathrm{Xi}+1$ : evaluation period $\mathrm{i}+1$;

$\mathrm{n}$ : total number of observations.

The statistical design was randomized blocks in subdivided plots, considering plots as the different species of wooden and fruit plants tested in consortium with the coffee trees and subplots as the different spacing.
For all variables, a 5\% probability was adopted for the $\mathrm{F}$ test. The analyzes were performed using the Sisvar computer program developed by Ferreira (2011). When significant differences were detected, the means were grouped by the ScottKnott test, at 5\% probability.

\section{RESULTS AND DISCUSSION}

The results concerning rust evolution curves in the intercropping and control treatments from November 2015 to November 2016 are presented on Figures 1 and 2.

The levels of rust began to rise from the month of February, but to a lower extent in the treatment with Teak, which provided lower rates of rust in relation to the other treatments. This may be explained by the characteristics of the plant, which belongs to a species considered shading, but lose the leaves during the dry season, therefore presenting a lower shading effect than the other species tested. The rust indexespresented a peak on September, when they were significantly higher in the macadamia and cedar species at smaller spacing and in the avocado, macadamia and cedar at larger spacing.

The area under the disease progress curve was calculated to evaluate the behavior of the disease throughout the studied period, which results are presented on Table 1.

The analysis of results presented on Table 1 demonstrated a significant interaction between the two spacing only for the treatment with avocado in consortium with coffee trees. Therefore, the different treatments were compared within each spacing used.

In the spacing 1 , the treatments with species teak and mahogany did not promote elevation in areas below the coffee rust curve even being inferior to the control, whereas the treatments with cedar and avocado provided area similar to the control and macadamia an area significantly higher in relation to treatments and control.

Regarding the spacing 2, the treatments related to intercropping of coffee with teak, mahogany and cedar presented areas below the coffee rust curve similar to the control in full sun, while the treatments of coffee intercropped with avocado and macadamia presented the highest areas below the coffee rust curve. The results observed agree with other results relating that shade mitigates temperature variation, intercepts light and probably increases moisture in the crop, and these effects favor the increase of rust, depending on the species used (MANCUSO et al., 2013). 

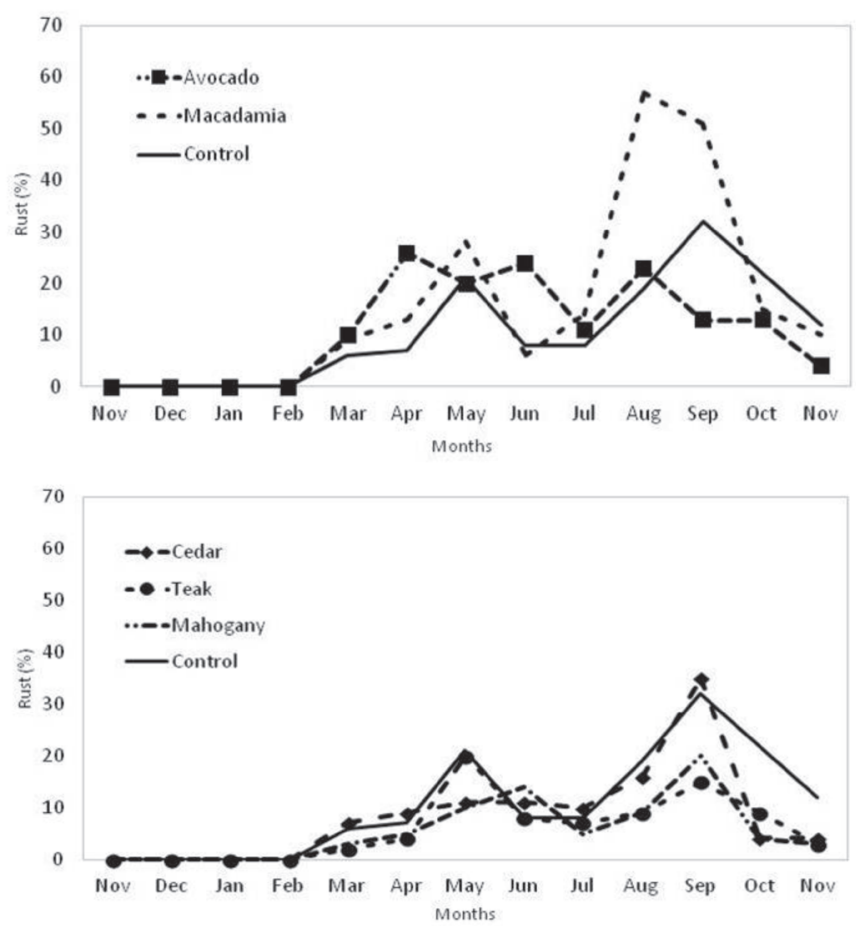

FIGURA 1 - Evolution of rust in trees with wooden species at spacing 9 x $13.6 \mathrm{~m}$ (A); fruit species at spacing $7 \mathrm{x}$ $13.6 \mathrm{~m}$ for avocado and 5x 13.6m for macadamia (B). Santo Antonio do Amparo, Minas Gerais.
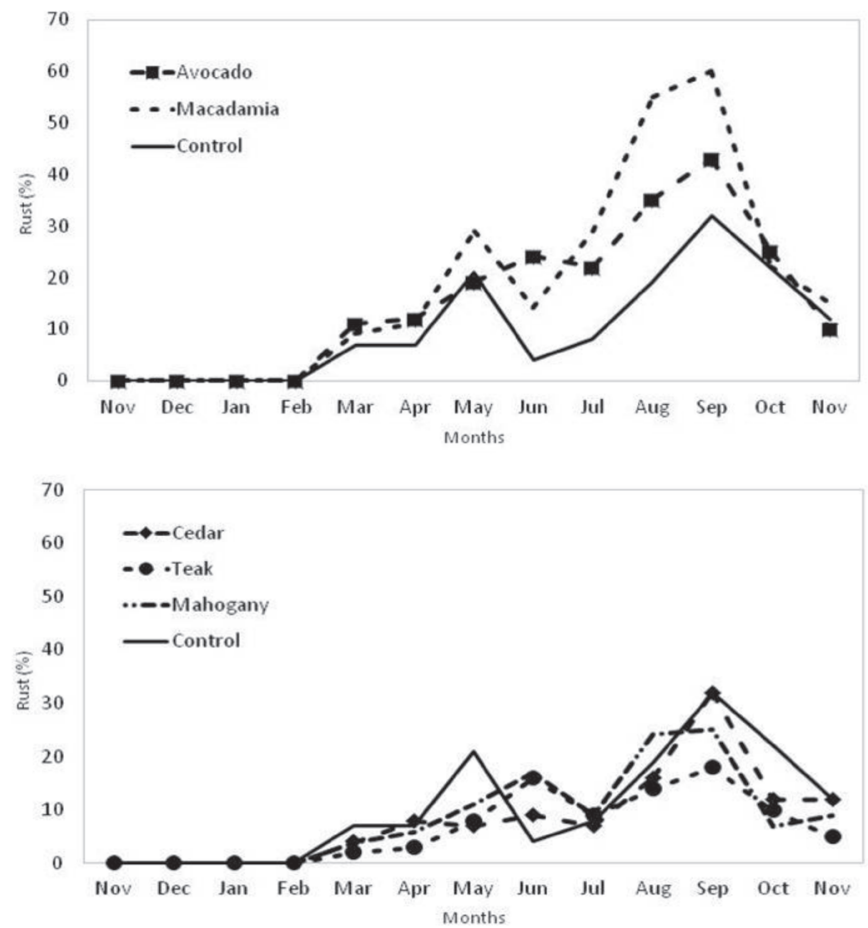

FIGURA 2 - Evolution of rust in trees with wooden species planted at spacing 14.0 x $13.6 \mathrm{~m}$ (A); Fruit trees planted at spacing $18.0 \times 13.6 \mathrm{~m}$ for avocado trees and $8.0 \times 13 \mathrm{~m}$ for macadamia (B). Santo Antonio do Amparo, Minas Gerais. 2015/16. 
On the other hand, there was no significant effect between treatments and spacing, except for the treatment with avocado that presented a larger area below the coffee rust curve in the larger spacing.

Considering that avocado is a good option for intercropping with coffee due to its high adaptability to environmental conditions and the possibility of generating additional income, especially for small coffee farmers (MANCUSO et al. 2013), further studies are necessary in order to shed light on the effect of different spacing over the incidence of rust observed in the present study.

One of the possible causes would be the competition exerted by some species used in the intercropping and consequent reduction of its productivity (GOVINDAPPA; ELAVARASAN, 2014). If there is competition of avocado with coffee trees and consequent reduction of productivity, the lowest rust index is justified, since the plant with less production becomes less susceptible to the incidence and severity of the disease.

In relation to the influence of climate (Figure 3 ) on the evolution of rust (Figs 1 and 2), it was observed that in all treatments the disease began to evolve from the month of February reaching a peak in the month of September, varying the intensity of rust among treatments with higher rust indices in species that presented higher canopy development, such as fruit species avocado and macadamia. In this way future research will be developed aiming to determine changes in the microclimates provided by the different species used in the consortium system.

TABLE 1 - Areas below the coffee rust curve in plantations intercropped with wooden and fruit species at different spacing. Santo Antonio do Amparo, Minas Gerais. Period of November 2015 to November 2016.

\begin{tabular}{lcc}
\hline Treatments & Spacing $1^{* *}$ & Spacing 2*** \\
\hline Teak & $61.00 \mathrm{a} \mathrm{A}$ & $76.00 \mathrm{a} \mathrm{A}$ \\
\hline African mahogany & $71.50 \mathrm{a} \mathrm{A}$ & $115.00 \mathrm{a} \mathrm{A}$ \\
\hline Cedar & $105.00 \mathrm{~b} \mathrm{~A}$ & $112.50 \mathrm{a} \mathrm{A}$ \\
\hline Avocado & $121.00 \mathrm{~b} \mathrm{~A}$ & $195.50 \mathrm{~b} \mathrm{~B}$ \\
\hline Macadâmia & $199.50 \mathrm{c} \mathrm{A}$ & $236.50 \mathrm{~b} \mathrm{~A}$ \\
\hline Control & $132.00 \mathrm{~b} \mathrm{~A}$ & $132.00 \mathrm{a} \mathrm{A}$ \\
\hline $\mathrm{CV}(\%)$ & 27.36 & 31.31 \\
\hline
\end{tabular}

* Means followed by the same lowercase letters in the columns and upper case in the rows belong to the same group by Scott-Knott's test at $5 \%$ of probability.

** Spacing 1: 9.0 x $13.6 \mathrm{~m}$ for wooden species; 7.0 x 13.6m for avocado and $5.0 \times 13.6$ for macadamia.

$* * * * * *$ Spacing 2: $18.0 \times 13.6 \mathrm{~m}$ for wooden species; $14.0 \times 13.6 \mathrm{~m}$ for avocado and $8.0 \times 13.6$ for macadamia.

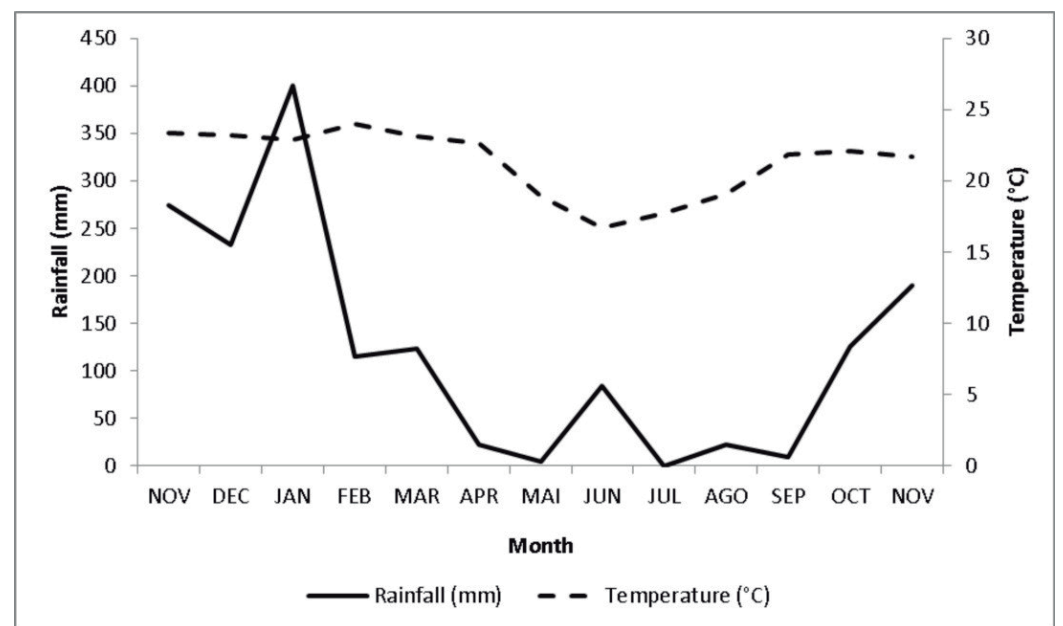

FIGURA 3 - Rainfall and temperature data during the period of November of 2015 to November of 2016.Santo Antonio do Amparo - MG. 


\section{CONCLUSIONS}

Coffee intercropping were favorable for the development of coffee rust in the conditions of the research developing. The continuity of the research will allow the verification of the consistency of the results, considering the dynamics of the environmental conditions and the development of the fruit and tree species tested in intercropping system with coffee.

\section{AKNOWLEDGMENTS}

Consórcio Brasileiro de Pesquisa e Desenvolvimento do Café-CBP\&D-Café; Fundação de Amparo à Pesquisa de Minas GeraisFAPEMIG.

\section{REFERENCES}

AGUIAR-MENEZES, E. L. et al. Susceptibilidade de seis cultivares de café arábica às moscas-das-frutas (Diptera: Tephritoidea) em sistema orgânico com e sem arborização em Valença, RJ. Neotropical Entomology, Londrina, v.36, n.2, p.268-273, mar/abr. 2007.

AVELINO, J. et al. The coffee rust crises in Colombia and Central America (2008-2013): impacts, plausible causes and proposed solutions. Food Security,New York, v. 7, n.2, p. 303-321,Mar/Apr. 2015.

AVELINO, J. et al. Topography and crop management are key factors for the development of american leaf spot epidemics on coffee in Costa Rica.Phytopathology, Davis, v.97, n. 12, p. 1532-1542, Dec. 2007.

BEENHOUWER, M; AERTSB, R; HONNAY, O. A global meta-analysis of the biodiversity and ecosystem service benefits of coffee and cacao agroforestry. Agriculture, Ecosystems and Environment, Oxford, v.175, p. 1-7, Aug. 2013.

BOTELHO, C.E. et al. Estratégias para convivência com o déficit hídrico.Informe Agropecuário, Belo Horizonte, v.36, n.285, p.50-58, 2015.

CARVALHO. et al. Desempenho agronômico de cultivares de café resistentes à ferrugem no Estado de Minas Gerais, Brasil. Bragantia, Campinas, v. 71, n. 4, p.481-487, out/dez. 2012.

DA MATTA, F.M.; RENA, A.B. Ecofisiologia de cafezais sombreados e a pleno Sol. In: ZAMBOLIM, L. (Ed.). O estado da arte de tecnologias na produção de café. Viçosa: UFV, 2002. p.93-135.
DAMATTA, F.M.; RODRÍGUEZ, N. Producción sostenible de cafetales en sistemas agroforestales en el neotrópico: una visión agronómica y eco-fisiológica. Agronomia Colombiana, Bogotá, v. 25, p. 113-123, 2007.

FERREIRA, D.F. Sisvar: a computer statistical analysis system. Ciência \& Agrotecnologia, Lavras, v.35, n.6, p.1039-1042, Nov/Dez. 2011.

GOVINDAPPA, M; ELAVARASAN,K. Shade cum fruit yielding avocado under coffee ecosystem. International Letters of Natural Sciences, Suíça, v. 22, p. 61-66, 2014.

IDOL, T; HAGGAR, J.; COX, L. 2011. Ecosystem services from small holder forestry and agroforestry in the tropics.p..209-270. In: Integrating agriculture, conservation, and ecotourism: examples from the field. W. CAMPBELL.;Lopez, S.(eds.). New York: Springer.

LASCO, R. D. et al.Climate risk adaptation by small holder farmers: the roles of trees and agroforestry.Current Opinion in Environmental Sustainability,Laguna.v.6, p. 83-88, 2014.

LOPEZ-BRAVO, D. F., VIRGINIO-FILHO, E. D. M.;AVELINO, J. Shade is conducive to coffee rust as compared to full sun exposure under standardized fruit load conditions. Crop Protection,v. 38, p.21-29, 2012.

MANCUSO, M. A. C.;SORATTO, R.P.; PERDONÁ, M. J. Produção de café sombreado. Colloquium Agrariae, Presidente Prudente, v. 9, n.1,p. 31-44, jan/ jun. 2013.

OVALLE-RIVERA, O. et al. Projected shifts in Coffea arabica suitability among major global producing regions due to climate change. PloS one, San Francisco/ Cambridge, v.10, n. 4, Apr. 2015.

PEZZOPANE, J.R.M. et al. Condições microclimáticas em cultivo de café conilon a pleno sol e arborizado com nogueira macadâmia. Ciência Rural, Santa Maria, v. 40, n. 6 , p. 1257-1263, jun. 2010.

SANCHEZ, E. et al. Shade has antagonistic effects on coffee berry borer. Proceedings of the 24th International Conference on Coffee Science (ASIC), November 11-16, 2012, 2013. San José, Costa Rica: ASIC.

STAVER, C. et al. Designing pestsuppressive multistrata perennial crop systems: shade-grown coffee in Central America. Agroforestry Systems,v. 53, n. 2, p. 151-170, Oct. 2001. 
SHANER, G.; FINNEY, R.E. The effects of nitrogen fertilization on the expression of slow mildwing in knox wheat. Phytopathology, Davis, v.67, p.10511055, Oct. 1977.

TSCHARNTKE T, et al. Multifunctional shade-tree management in tropical agroforestry landscapes: A review. Journal of Applied Ecology, London, v. 48, n. 3, p. 619-629. May/June. 2011.
VALENTINI, L.S.P. et al. Temperatura do ar em Sistemas de Produção de café Arábica em monocultivo e arborizados com seringueira e coqueiro-anão na região de Mococa, SP. Bragantia, Campinas, v. 69, n.4, p.1005-1010, out/dez. 2010.

WRIGLEY, G. Coffee. New York: Longman Scientific Technical and John Wiley \& Sons. 1988. 639 p. 